\title{
Internal Control Weakness: A Literature Review
}

\author{
$\mathrm{Yu} \mathrm{Lu}{ }^{1} \&$ Diandian $\mathrm{Ma}^{2}$ \\ ${ }^{1}$ Business School, Beijing Technology and Business University, 11/33, Fucheng Road, Beijing, 100048 China \\ ${ }^{2}$ Business School, University of Auckland, 12, Grafton Road, Auckland, 1142, New Zealand \\ Correspondence: Yu Lu, Business School, Beijing Technology and Business University, 11/33, Fucheng Road, \\ Beijing, 100048 China
}

Received: February 3, 2019

Accepted: March 31, 2019

Online Published: April 3, 2019

doi:10.5430/afr.v8n2p121

URL: https://doi.org/10.5430/afr.v8n2p121

\begin{abstract}
The purpose of this essay is to review empirical literature on internal control weakness over the past seven years. I use an analysis framework consisting of determinants (corporate governance and other affecting factors) and economic consequences (accounting information quality, market reaction, cost of equity, debt contracting) of weakness disclosure and its remediation. Basic findings of prior studies agree that corporate governance and firm characteristics influence the presence of control problems and their remediation. In turn, the effectiveness of internal control impacts the quality of financing reporting, auditor reaction (auditing fees and audit delays), insider trading and leads to capital market consequences (the weakness disclosures affect debt contracting). More internal control studies combine with capital market and provide evidence that SOX are not always effective. Overall, these findings contribute to profession by suggesting that the disclosures of internal control deficiencies generally convey incremental information on the quality of financial reporting to investors. This review integrates and assesses current internal control weakness research and offers some suggestions for future study.
\end{abstract}

Keywords: internal control weakness, literature review

\section{Introduction}

After a series of serious internal control scandals, the USA government passed the Sarbanes-Oxley Act (SOX 2002) in order to improve financial reporting quality (Calderon et al. 2012) and restore the confidence of investors in the capital market (Burrows 2011). A firm and its auditor are required to disclose deficiencies of internal control and provide annual opinions under Section 302 and 404 of SOX. Internal control weaknesses are required to be disclosed. What are the causes and consequences of the weaknesses of internal control over financial reporting? In response to this question, a considerable amount of academic research has examined the disclosure of internal control deficiencies under SOX 302 and 404. This paper reviews forty contemporary articles regarding internal control weakness published in leading accounting journals (Note 1) from 2005 to 2012. I subdivide these studies into three topics: determinants of control weakness, economic consequences of weakness disclosures and weakness remediation.

\section{Literature Review of Internal Control Weakness}

\subsection{Determinants of Internal Control Weakness}

A substantial body of literature has examined the determinants of internal control deficiencies using voluntary or mandatory data prior to or after SOX 302 and 404. These literature provides indirect or direct evidence on factors that influencing weaknesses in internal control over financial reporting.

In the period when disclosure was voluntary, there are few articles about internal control disclosure due to the unavailability of data. According to descriptive statistics of Bronson et al (2006), none of management reports on internal control disclose material weakness; about forty percent of reports disclose that their internal controls are effective and only three report assessment criteria of internal control effectiveness.

After internal control information was disclosed mandatorily, there are increasing members of empirical articles. Based on specific-style material weakness disclosure provided by management pursuant to SOX 302, Ge and McVay (2005) offer descriptive evidence that inappropriate allocation of resources for accounting controls, deficient revenue-recognition and accounting policies, insufficient account reconciliation, lack of segregation of duties, deficiencies in the period and complex accounts increase the likelihood of material weakness. Subsidiary-specific 
and current accrual account-specific material weaknesses are quite common. Then Ge and McVay (2005) empirically analyse firm characteristics related to internal control deficiencies and find that companies with complex business, small size, less profit and audited by a large accounting firm tend to disclose material weaknesses. They also emphasize that the root of deficiencies stems from personnel issues. Using post-SOX evidence, Doyle et al. (2007a) confirm the findings of Ge and McVay (2005) but add that young age, rapid growth and restructure are consistently positively correlated to weaknesses. Furthermore, Doyle et al. (2007a) posit that the determinants vary in light of weakness classifications. More severe entity-wide issues are more pervasive in young, small and weak financial companies, while less serious account-specific issues exist in healthy financial, diversified complex and rapidly changing firms. Firms with staff-related problems tend to be financially weak and smaller, while firms with complexity-related problems have complex, diversified and rapidly changing operations.

However, Ge and McVay (2005) and Doyle et al. (2007a) mainly focus on material weakness in internal control. Ashbaugh et al. (2007) develop Ge and McVay (2005) and Doyle et al. (2007a) by investigating all three kinds of internal control weaknesses (control deficiencies, significant deficiencies and material weaknesses, PCAOB 2004). Based on non-mandated data under SOX 302, Ashbaugh et al. (2007) study the reasons why firms expose control weaknesses and the incentives of management to discover and report control deficiencies. The findings show that fewer resources, organizational changes, accounting risk, auditor resignations and complex operations are positively associated with the disclosure of control deficiencies. The incentives for discovering and reporting control problems are usually relative to concentrated institutional ownership, prior SEC enforcement actions, whether audited by a dominant accounting firm and financial restatements. Leone (2007) argues that the paper of Doyle et al. (2007a) and Ashbaugh et al. (2007) provide a starting point for the future study regarding the consequences of control deficiencies. Consistent with the results of Ge and McVay (2005), Doyle et al. (2007a) and Ashbaugh et al. (2007), Petrovits et al. (2011) find the similar factors cause control problems in non-profit organizations.

Different from Ashbaugh et al. (2007), Rice et al. (2012) examine directly the determinants of reporting decisions and effectiveness under SOX 404. Their design centres on restating firms because the misstatements of restating firms are more likely to be linked with underlying material weaknesses. They conclude that only a minority of sample firms report their existing material weakness during the misstatement periods, and that the percentage has declined over time. The findings suggest that, in identifying existing material weaknesses, SOX 404 is not always effective and has not been improved over time. In addition, they also find that internal factors (few financial distress and few reported material weaknesses and restatements) and external factors (external capital, audit firm size, less auditor effort, few changes of auditor and non-audit fees) are positively related with higher probability of disclosing existing control problems.

Prior studies of determinants (Ge and McVay, 2005; Doyle etal.2007a; Ashbaugh-Skaife et al. 2007) restrict solely to financial characteristics, while Li et al. (2010) extend (Ge and McVay, 2005; Doyle et al.2007a; Ashbaugh-Skaife et al. 2007) by testing whether the qualifications and turnover of CFOs are determinants of SOX 404 material weakness. $\mathrm{Li}$ et al. (2010) offer evidence that less qualified CFOs (whether he or she has a CPA license or has worked in a pubic audit firm, how many years he or she worked as a CFO) and more CFO turnover are more likely related with adverse SOX 404 opinions. Similarly, Masli et al. (2010) study the potential benefits of monitoring technology on internal control. Using 152 firms from 2003 to 2006, they find that there is a negative relation between the implementation of monitoring technology and material weaknesses. Cassar and Gerakos (2010) study the determinants of hedge fund internal control. The results show that high potential agency costs, managers of funds domiciled offshore, levered and young funds are related to strong internal control. The findings also indicate that there is a positive relation between internal control quality and performance fee rewarded to managers. This suggests that internal controls seem less likely to detect or prevent earnings management of managers.

As noted above, empirical findings consistently indicate that internal control deficiencies are often related with firms characteristics including internal factors (firm size, firm age, business complexity, profitability, organizational changes, financial distress, financial health, accounting risk, growth, structure, resource availability, past weakness and restatements, change in qualifications and turnover of CFOs, management changes, corporate governance and monitoring technology) and external factors (external finance, audit firm size, auditor resignations and changes, auditor effort and non-audit fees). Future study on more factors affecting deficiencies such as company culture might be conducted. Specially, the results of prior studies show that some characteristics of board of directors, audit committees, top management, CEO and CFO are linked with material weakness. 


\subsection{Internal Control Weakness and Corporate Governance}

SOX and its regulations provide an increased emphasis on corporate governance (Hoitash et al. 2009). It is important to test monitoring mechanisms (corporate governance and audit committee) that can be used to reduce internal control weaknesses. The accounting profession and policy makers maintain that one of the primary functions of corporate governance (Note 2) especially audit committee should be the oversight of internal control (Krishnan 2005). Anecdotal evidence and academic research indicate audit committees consider internal control as their function. While it seems clear that corporate governance especially audit committee are expected to play a key role in reduce control weaknesses, what happen in reality (Krishnan 2005)? In response to this practical question, many studies have examined the relationship between internal control and corporate governance especially audit committee based on corporate governance theory.

Corporate governance and internal control are associated closely together and influence each other (Li 2007). In addition, internal control quality is a function of the quality of control environment including board of directors, audit committee and other non-governance controls (Krishnan 2005).

Many researchers have examined the effect of audit committee on internal control under SOX 302 and SOX 404. Krishnan (2005) tests the relation between audit committee composition and the quality of internal control using firms that changed auditor over the period prior to the enactment of SOX. The empirical results show that the independence and the numbers of financial experts of audit committees are significantly negatively related with both levels of internal control problems (less severe reportable conditions and more serious material weaknesses). The findings also indicate that auditor tenure, financial stress, CFO, CAO or Controller' work experience and tendency to engage in fraud are linked with the incidence of control problems. However, board of directors, internal audit function and external auditor are not found to be associated with internal control problems. In contrast, by using large sample of the post-SOX period (all firms are required to disclose material weakness under SOX), Zhang et al. (2007) overcome sample size problem of Krishnan (2005). Zhang et al. (2007) examine the association between audit committee quality, auditor independence and internal control weaknesses. They present evidence that the disclosure of material weakness is positively related with less audit committee financial expertise, especially linked with less accounting financial expertise and non-accounting financial expertise. They also argue that material weakness disclosure is positively with auditor changes and auditor independence.

Although a weak association between material weaknesses and supervisory or user expertise is reported by Zhang et al. (2007). Krishnan (2005) and Zhang et al. (2007) do not assess specific-style control problems. Hoitash et al. (2009) divide material weakness by source and classify financial expertise according to type (accounting, supervisory and user). Hoitash et al. (2009) employ material weakness under both SOX 302 and 404 to investigate how governance characteristics affect internal controls quality. They note that less audit committee members with accounting and supervisory experience and board strength, delegating financial experts without accounting experience or multiple financial experts as audit committee members all lead to material weakness. They also find evidence that only accounting financial experts are related with the disclosure of account-specific control issues, while only supervisory financial experts are linked with the disclosure of management-oriented problems on personnel and information technology. Both accounting and supervisory expertise are related with better internal controls, while "user" financial experts are found to be related with more material weakness disclosure. This suggests that the nature of material weakness varies with the type of experiences. However, all relationships are only detectable under more stringent SOX 404 rather than less stringent SOX 302. Therefore, different regulatory requirements influence the association between corporate governance and internal control.

Apart from independence and expertise, other audit committee characteristics such as turnover and former audit partners have also been studied in previous literature. Srinivasan (2005) focuses on firms that experience accounting restatements and study the penalties for outside directors. He offers the evidence that outside directors bear reputational costs when their companies report income-decreasing restatements. Further, he reveals that higher turnover of boards especially audit committee links to more technical restatements. He is followed by Johnstone et al. (2011). They employ four-year data of SOX 404 disclosures to explore the correlation between material weakness and turnover of audit committees, board of directors and top management. Positive associations are found in their paper. In terms of former audit partners, Naiker and Sharma (2009) consider how material weaknesses under SOX 404 are influenced by the presence of affiliated former audit partners (AFAPs) and unaffiliated former audit partners (UFAPs) on the audit committee. The empirical results show that there is a negative association between AFAPs, UFAPs and material weakness. The findings suggest that the expertise possessed by former partners offer significant contribution to more effective internal control. They contribute to practisers by arguing that independence concerns 
on "revolving-door" appointments and three-year "cooling-off" rule could not be warranted. In other words, imposing restrictions to appointing experienced and qualified experts as audit committee members are largely ineffective.

Internal auditors support managers to take the responsibilities for internal control (Institute of Internal Auditors IIA 2004, 3). Lin et al. (2011) examine the association between internal audit and material weaknesses under SOX 404. Using the data of 214 firms from 2003 to 2004, they find that there is a negative relation between material weakness and the education level, the extent of internal audit includes quality assurance techniques into fieldwork, audit activities associated with financial reports and monitoring of weakness remediation. The quality of internal auditing prevents the incidence of material weaknesses. They also find that there is a positive relation between material weakness and internal auditing of auditing engagement and external coordination of internal auditor, which improves internal control effectiveness.

Few studies examined the impact of control deficiencies on corporate governance. Wang (2010) examines the relation between increased internal control mandated requirements and corporate governance on CFOs before and after SOX. The results show that weak control result in lower compensation and higher turnover of CFOs after SOX. While strong control leads to higher compensation and insignificant changes of turnover of CFOs. This suggests that mandatory disclosures identify effectively good and bad CFOs and reduce information asymmetry in the executive labor market. From the perspective of insider trading, Skaife et al. (2012) investigate the relation between internal control and managerial rent extraction under SOX 404. They posit that internal control material weakness may result in greater profitability of insider trading. Using the sample of 4505 firms during the period from 2004 to 2008, they observe that the firms disclosed material weakness benefit more from inside trading. Further, they find that top managers are lack of integrity. They also find that weak "tone at the top" CEOs and CFOs tend to leave the firms when they engage in insider trading with more profit. Overall, the findings suggest that manager selling the shares of firms is a greater risk of wealth transfer from shareholders to managers.

However, the research of this area is a study of association, not causation (Carcello and Neal 2003; Doyel et al. 2007b; Naiker and Sharma 2009). Some unobserved factors that relating to internal control and audit commit characteristics might influence the reported results. For example, there are many monitors of internal control. Prior studies control manager quality, top management, board of director, internal audit, external auditor, financial stress and firm growth. But other factors including firm culture, top management team, human capital, social capital and characteristics differences of board of directors and managers should also be controlled. After controlling those variables affecting internal control, the results may be change. The control variables in prior studies are not adequate to some extent. This may reduce the power of results. But omitted variables problem is common in empirical models. Future studies should control these important factors in the regression model in order to get more reliable results.

Most of previous studies focus on audit committees' characteristics and the results suggest that audit committee makes more contribution compared than other monitors. However, according to American laws and regulations, management is responsible for the implementation and perfection of internal control effectiveness. Management pays attention to the whole process of internal control while audit committees only supervise internal control. This suggests that management plays a more important role than audit committees. For instance, American Auditing Standards Board No. 55 Auditing Standards (1995) indicate that to establish and maintain internal control system is an important management responsibility. Managers bear the fundamental responsibility of the internal control system and have the ownership of the system (COSO 1992). SOX (2002) granted internal control responsibilities to the CEO, which combines corporate governance and internal control. In the future, more research regarding the impact of management on internal control is needed. For example, whether and how the characteristics of managers influence internal control? What is the different impact between top management team and key manager? Whether managers of different levels influence internal control in different way? Whether heterogeneous capitals of managers affect internal control?

In summary, past paper has studied empirically the influence of corporate governance on material weakness before or after SOX 302 and SOX 404. The characteristics of audit committees, board of directors, internal auditor, top management and experts (independence, experience, expertise, strength, turnover, auditor tenure, financial stress, fraud tendency and former audit partners), are found to be generally associated material weakness. In turn, ineffective internal control causes higher profitability of insider trading. However, earlier work (e.g. Krishnan 2005; Zhang et al. 2007; Hoitash et al. 2009) tends not to address a linkage of audit committee size and control problems. Moreover, in terms of endogeneity, changing in corporate governance and internal control may be an element of a 
board response to material weakness disclosures (Johnstone et al. 2011). In general, the quality of corporate governance, particularly audit committee is associated with the disclosure of material weakness. But they just focus on American firms and study some characteristics. Moreover, characteristics of board of directors are just control variables rather than interest variables in their research. Given to the importance of board, it would be interesting to study the influence of human capital, social capital and characteristics differences of board of directors and managers on internal control effectiveness. Based on management theory, leadership theory, human capital theory, human nature theory, top manager theory entrepreneur theory, cognitive psychology theory, behavioral accounting theory, heterogeneous human and capital theory, future research may further study above issues.

\subsection{Economic Consequences of Weaknesses Disclosure}

Historically, empirical studies evaluating capital market consequences of the SOX legislation are quite recent with a variety of published studies. This section summaries studies in prior literature regarding economic consequences of weakness disclosures from five aspects: accruals quality, auditor reaction, market reaction, cost of equity and debt contracting.

\subsubsection{Internal Control Weakness and Accruals Quality}

Issues related to earnings quality have been studies for many years. However, regarding the matter of internal control, the related research is limited due to the unavailability of data before SOX. The passage of SOX provides a research opportunity for internal control and accounting information quality.

Doyle et al. (2007b) explore the association between internal control environment and accruals quality during the SOX 302 and 404 regime. They claim that only SOX 302 disclosures appear to be linked with poorer earnings quality compared to SOX 404. After they break disclosures down into account-level and company-specific, they illustrate that only overall company-specific problems (versus account level) drive strongly low accruals quality for both SOX 302 and 404. Interesting, they find no differences in earning quality for material weakness under SOX 404 regardless of whether the firms disclose deficiencies or not. Their findings imply that SOX 302 and 404 do not seem to be effective and appropriate at identifying poor quality companies. But at least company-wide weaknesses link partly to poor-quality accruals. In a similar study, Ashbaugh et al. (2008) employ SOX-mandated data to investigate how control problems influence accruals quality. They offer strong evidence that the presence of control deficiencies result in more reliable financial reporting measured as low-quality accruals by reducing unintentional and intentional misstatements. Further, a causal association between internal control effectiveness and accrual quality is found in successive years.

However, previous research primarily focused on US setting. Van de Poel and Vanstraelen (2011) examine internal control and accruals quality in an alternative regime. Based on "comply-or-explain regime in Dutch, they find that the description of internal control system is not related with the provision of accruals quality information. But effective internal control is positively related with accruals. They also find that few firms disclose management statement on internal control. Their findings contribute to the debate on internal control regulation based on global regime.

Different form the focus on earnings quality in prior studies, Feng et al. (2009) posit that material weaknesses may influence the accuracy of earning guidance through reducing the quality of management reports that generating forecasts. Using 2994 accelerated filers form 2004 to 2006 under SOX 404, they conclude that control problems not only influence earning quality, but also result in less accurate management guidance.

With regards to conservatism, Goh and $\mathrm{Li}$ (2011) study the association between internal control and conditional conservatism under both SOX 302 and 404. The results show that internal control quality is positively related with conservatism. In particular, material weaknesses result in lower conservatism. The findings suggest that strong internal control facilitate conservatism.

In sum, previous literature provides empirical evidence that effective internal control leads to high-quality financial reporting. However, they only use accruals and conservatism as proxy variable of financial reporting quality. Future studies could consider other ways to measure exactly and completely accounting information.

\subsubsection{Control Deficiencies and Auditing Process}

There are two explanations on why control deficiencies results in lower accruals quality. One is that weak internal control leads to low earnings quality. Auditors might not detect or correct potential misstatements. An alternative interpretation is that auditors do recognize control risk and attempt to extend efforts to detect risk (Hogan and Wilkins 2008). In order to study the second possibility, Hogan and Wilkins (2008) examine whether control 
deficiencies increase audit fees. Using data under SOX 302 from November 2003 and November 2004, they find that audit fees are high significantly for firms that disclosed control deficiencies. Particularly, audit fees are highest for material weaknesses. As audit fees may proxy for audit effort to some extent, they also find that auditor increase the efforts when control deficiencies exist. Additional analysis shows that audit fees are higher for control deficiencies no matter whether they are audited by Big 4. Further, audit fees are high for control deficiencies firms with auditors for one or second year compared to longer tenure. This suggests that auditor type and tenure influence auditor responses to control deficiencies.

Similarly, Hoitash et al. (2008) investigate the association between control quality and audit pricing under SOX 302 and 404. By using the data of 350 firms form November 2004 to October 2005, they observe that there is a positive relation between control problems under SOX 404 and audit fees. The result suggests that greater auditor efforts require more expenditure or result in risk compensate for residual risk of auditor when firms disclose control problems under SOX 404. The also find that audit fees are significantly related with material weakness, but they fail to find any correlation for significant deficiencies. This suggests that audit fees vary with deficiencies severity under SOX 404. In addition, they find that audit fees are significantly related with problems that affecting multiple accounts. For account-level problems, audit fees are higher for accruals, revenue recognition and least problems. This implies that based on multiple dimensions, auditors identify control problems. Lastly, they observe that in the Section 302 period, audit fees changed more than Section 404. The results suggest that increased audit costs of healthy firms cause inefficient resources allocation under Section 404. Further, firms without disclosing control deficiencies under SOX 404 but with the deficiencies disclosure under SOX 302 still pay higher audit fess. This finding indicates that auditors are making more efforts to test control problems or they assess and pricing the possibility of control deficiencies that are not found. Additionally, under both sections, firms that report control problems are observed to be related with higher risk than those companies report for the first time under SOX 404. Take as a whole, they offer evidence for audit risk adjustment in the initial period of SOX regulations.

In terms of timeliness issue, Ettredge et al. (2006) study how the assessment on internal control quality under SOX 404 affects audit delay. The results indicate that material weakness is linked with longer audit delays. Specially, general material weakness is related with longer delays than specific problems. The problems such as personnel, process and procedure, segregation of duties and closing process are associated with longer audit delays. Overall, they provide evidence that SOX 404 assessments are significantly related with long audit delay. The findings suggest that it is hard for firms to shorten deadlines of 10-K filings according to the desire of SEC under SOX 404. This supports the decisions of SEC that to defer for one year for large and accelerated filers of 10-K filing. Munsif et al. (2012) extend Ettredge et al. (2006) by using a later time period and examining both accelerated and non-accelerated filers. The results show that audit lag in the presence of control weaknesses increase lowly for non-accelerated in 2008. But the impact of control deficiencies on audit lag is lower for accelerated filers in 2009. The results also indicate that the small accelerated filers are smaller to other accelerated filers and different from non-accelerated for auditors in terms of the relation between audit lag and control deficiencies. Take as a whole, they offer evidence on the extent of audit effort related to control deficiencies. The evidence suggests that accelerated and non-accelerated companies are quite different on auditor services.

In sum, internal control weakness influences the process of auditing from auditing fees and audit delay. Material classification, auditor type and tenure influence auditor responses to control deficiencies. In turn, audit fees are significantly related with the disclosure of control deficiencies. Also, material weakness is linked with longer audit delays.

\subsubsection{Market Reactions of Weakness Disclosures}

With regard to market reactions to the disclosure of internal control, empirical evidence has been mixed. Defond et al. (2005) examine cumulative abnormal returns around the announcement of the appointment of outside directors to audit committee before SOX era. The results of event study and multivariate analysis show that the market reacts favourably to the appointment of accounting financial experts, but there is no reaction to non-accounting financial experts. The results also reveal that positive reaction is concentrated only when corporate governance is relatively strong. The findings document that context impacts the ability of financial experts to improve corporate governance. Similarly, Hammersley et al. (2008) test whether stock price reacts to weaknesses disclosure of SOX 302. They control other announcements in the event window and report that severity, auditability, management's conclusion on the effectiveness and vagueness of the disclosures are informative. They also find that the information contents of weaknesses disclosures vary on the severity of the weaknesses. That is, material weakness drives the association between return and vagueness. The negative price reactions to the disclosure of control weaknesses are generated in 
a clear sub-sample. Further, Beneish et al. (2008) assess the capital market reactions to SOX 302 and 404 disclosures using a short window. They claim that disclosures under SOX 302 have noticeably negative announcement abnormal returns. In contrary, the firms making SOX 404 disclosures experience no significant stock price. In sum, deficiencies disclosures are viewed conversely or not viewed by market participants. Kim and Park (2009) extend Beneish et al. (2008) by testing the association between market uncertainty, market reactions and control problems under Section 302. Using 608 firms in 2004, they find that abnormal stock returns negatively relate with the changes of market uncertainty when control deficiencies are disclosed. They also find that reduced uncertainty has greater influence on voluntary disclosures of non-material weaknesses.

In terms of risk assessment of investors, Rose et al. (2010) study whether material weaknesses influence the perceptions of investment risk evaluation under SOX 404. The results of experiments indicate that the disclosures of material weaknesses and the details of the pervasiveness of material weaknesses make investors adjust risk assessment. The findings also show that material weaknesses pervasiveness and disclosure detail are interactive. Investors increase risk assessment when material weaknesses are not pervasive and include both specific and detained disclosures. This suggests that various levels of management investor trust drive the results.

Overall, the results of market reactions of the disclosure of internal control are mixed. Further research need to re-examine this issue by recent and long-term data such as five-year data after the mandatory disclosure of requirement.

\subsubsection{Cost of Capital and Control Weakness}

Several research questions costs versus benefits regarding internal control regulation under SOX. The studies pertain to cost of capital yield mixed results. For instance, Beneish et al. (2008) use a sample of both SOX 302 and 404 to assess whether weaknesses are related to cost of equity capital. They find that high implied cost of capital is associated with SOX 302 disclosures. However, they fail to find evidence that cost of equity is impacted by the disclosures of SOX 404. Consistent with Beneish et al. (2008), Ogneva et al. (2007) are also unable to find higher cost of equity linking with internal control weakness under Section 404. The conclusions of Beneish et al. (2008) and Ogneva et al. (2007) suggest that the disclosures of internal control weakness have no potentially noticeable cost-of-equity benefits. But there have been dissenting voices, Ashbaugh et al. (2009) offer clear evidence that internal control deficiencies impact cost of equity and firm risk under SOX 302 and 404. Results show that internal control weakness leads to low-quality financial reporting, which in turn increases the information risk that manifesting in high cost of capital.

From the perspective of debt market, Schneider and Church (2008) conduct an experiment to examine how auditor's opinions on internal control influence loan decision under SOX 404. They find that adverse opinion may have negative impact on the assessments of lenders. Additional test indicate that adverse opinion weakens the importance of balance sheet and income statement in the decisions of lending and reduce the confidence of lenders. Recent literature (Kim et al. 2010; Costello et al. 2011; Dhaliwal et al. 2011) adds to the debate on the cost benefit trade-offs of SOX. Costello et al. (2011) examine whether weakness disclosures have an impact on debt contracting under Section 302. Results show that internal control reports allow for the effectiveness of debt contracting. Accordingly, lenders decrease the use of financial covenants and substitute financial-ratio-based performance pricing provisions with alternatives when they face with weakness report. Also, lenders impose tight monitoring on managers (add general covenants and decrease loan maturity), but do not decrease the use of financial covenants and financial-ratio-based performance pricing provisions. However, Costello et al. (2011) only use weakness sample, which might limit their inferences. Kim et al. (2010) evaluate how control problems affect bank loan contracting by comparing firms disclose weakness and those without disclosure under SOX 404. They find that high direct and indirect costs of bank loans are associated with control weaknesses. Further, banks charge higher loan rates after weaknesses disclosure and charge lower loan rates after weaknesses remediation. Entity-level control problems associate with higher loan rates compared to account-specific issues. Take as a whole, the results show that when banks set the price and non-price terms of loan contracts, internal control deficiencies are taken into consideration. Dhaliwal et al. (2011) examine the relation between internal control, monitoring and debt cost under SOX 404. The results also show that the disclosure of material weaknesses results in high cost of debt. Additionally, the results are more significant when firms are not monitored by credit rating agencies and banks. This suggests that bank is an effective monitoring. Overall, prior results suggest that credit stakeholders in the debt market consider material weakness as an information-risk-increasing factor.

Motivated by the requirement of SOX 404 that auditor provide opinions on internal control, Lopez et al. (2009) examine the perceptions of investor of adverse internal control audit opinion. Eighty one MBA students (with 
average four-year work experience) participate this research. The authors find that adverse audit opinion associated with unqualified opinion related significantly to lower financial statement transparency, lower sustainability of earnings, lower earning predictability, higher risk of current and future financial reporting, higher information asymmetry, higher risk premium, higher cost of capital, and higher capital cost of the investor assessment. This suggests that adverse audit opinion covey incremental value relevant information to financial statement users.

In terms of the consequences of control problems in non-profit organizations, Petrovits et al. (2011) find the disclosure of control problems result in less subsequent donor support by examining 27495 non-profits organizations from 1999 to 2007. They also find that control problems cause the reduction of subsequent government grants. This suggests that control problems influence directly or indirectly the giving decisions of funders in public charities.

To sum up, effective internal control leads to high-quality financial reporting, low auditing fees and short audit delays and influence the funders' giving decisions. However, there are no agreement opinions towards market reactions to the disclosure of internal control. Further, in terms of the debate of cost and benefits of internal control disclosure, the findings are confounded. The loan contracting consequences of weaknesses disclosure have been corroborated while there are some inconsistencies and uncertainties upon whether control problems impact cost of equity. More statistical analysis on capital market consequences of internal control disclosures from various perspectives are demanded for future's research.

\subsection{Weakness Remediation}

SOX 404 require firms to disclose annual non-remediated material weakness. Recent work has examined the causes and consequences of remediation activity.

Few studies examine determinates of remediation. For example, Li et al. (2010) attempted to offer a comprehensive understanding of the relation between qualification improvement, turnover of CFOs and weaknesses correction. They conclude that remediation firms tend to experience more turnovers of CFOs and hire CFOs having better qualifications. Results imply that hiring a subsequent new qualified CFO exhibits an improvement in fixing material weaknesses. In terms of corporate governance, Johnstone et al. (2011) evaluate whether changes in corporate governance affect subsequent weakness remediation. The findings show that turnover of audit committee members (rather than board members, CEOs and CFOs) relates positively with remediation. If there are more independent directors and financial expertise on boards, audit committee members have more shareholdings, an audit committee member acts as chairman, then remediation would be improved. Additionally, the greater accounting expertise, work experience and good reputation of CFO benefit to weakness remediation. Results also reveal that the presence of more material weaknesses and general level (versus specific type) has negative relation with remediation. Skife et al. (2012) investigate whether internal control effectiveness influences the insider trading profitability. The results show that there is no relationship between insider trading and weakness remediation.

Beyond determinants, remediation and accounting information quality has also been studied in past articles. Ashbaugh et al. (2008) examine the impact of deficiencies remediation on accrual quality and find that the firms whose auditor confirmed remediation of previous reported maternal weaknesses exhibit noticeable improvement in accrual quality compare to the firms that fail to remediate weaknesses. However, early studies do not evaluate remediation by specific weakness type. Bedard et al. (2012) examine remediation of material weakness of specific types and whether different levels of remediation vary with changes in earnings quality. The results suggest that company-level weaknesses are linked with lower likelihood of remediation. Results also show that the two remediation types (company-level and account-level) both improve significantly earnings quality. Specially, some company-specific (accounting reconciliation, information technology and segregation of duties) and some account-level (revenue, tax, inventory and receivables) remediation types are slow but significantly tied to change in abnormal accruals. In terms of conservatism, Goh and $\mathrm{Li}$ (2011) observe that material remediation causes greater conservatism compared to firms without remediation by examining under SOX 302 and 404.

With regards to timeliness, Munsif et al. (2012) study the relation between weaknesses remediation and audit lags. They observe that audit lag is short for the firms with remediation disclosure. While those firms have higher lags compare to the firms without remediation under SOX 404 in both 2008 and 2009. This suggests that material weaknesses cause the reduction of audit lag.

Summing up, similar to the disclosure of internal control deficiencies, contemporary research has studied determinants, insider trading, accruals quality, audit lags and remediation by specific weaknesses type of SOX 404. The findings consistently imply that disclosure structure under SOX 404 should be improved. However, recent and long-term sample is needed to be re-examined in further research of market reaction. For example, five-year data 
after the mandatory disclosure of requirement can be used to measure market reaction. More research such as economic consequences of remediation disclosure is called for in the future.

\section{Measurement of Weakness}

Recent articles search internal control data from Audit Analytics database, EDGAR database, Compliance Week and SEC filings. Internal controls are dependent variable, independent variable or control variable in different research. If internal control problems are dependent variable, most studies build logistic regression model as the presence of control problems is an indicator variable.

The disclosure of internal control deficiencies and their remediation is a dummy variable in the majority of papers, which is coded as 1 if the firm discloses related information, and 0 otherwise. Most of work measures the quality of internal control by employing whether the firm discloses material weakness (Ge and Mcvay 2005; Krishnan 2005; Ogneva et al. 2007; Zhang et al. 2007; Ashbaugh et al. 2007; Ashbaugh et al. 2009). They view the detection and disclosure of control problems as a process. But Rice et al. (2012) separate them into two sequential processes. Specially, in order to measure the specific-type control weaknesses, a number of studies develop a series of indicators. Doyle et al. (2007a; 2007b), Beneish et al. (2008), Naiker and Sharma (2009) and Kim et al. (2010) use company-level and account-specific weakness indicators. In addition, Doyle et al. (2007a) classify material weakness depending on reasons of weakness: staff, complexity and general. While Hammersley et al. (2008) code control problems from five aspects: severity, effectiveness, auditability, vague, discovered by and Big Four auditor. In terms of remediation, Johnstone et al. (2011) and Bedard et al. (2012) study specific remediation type. Johnstone et al. (2011) measure material types according to the COSO framework elements and Bedard et al. (2012) define multiple deficiencies by checking whether the number of different problems types is greater than the mean value. While other paper (Ashbaurh et al. 2008; Naiker and Sharma 2009; Li et al. 2010) use unqualified audit opinion as proxy variable of internal control problems.

Different from other researchers, Johnstone et al. (2011) take into account the extent and nature of control problems according to the COSO framework elements. They not only examine whether control problems are disclosed, but also study the degree of weaknesses disclosure. They use the sheer number of material weaknesses to proxy for the extent of control weaknesses. With regards to the nature of material weaknesses, they employ six dummy variables. Apart from general material weaknesses, they also control particular elements including control environment, risk assessment, control activity, internal supervisor, information and communication. Further, Cassar and Gerakos (2010) build an index to measure overall quality of hedge internal control. But this index only bases on whether management involvement is included in internal control. Similarly, Bodnar (1975) and Hmtden (1980) proposed internal control evaluation models. Gerry (2000) (Note 3) summarizes the number of internal control deficiencies based on the 21 categories reported in the Audit Analytics database, ranked by the number and percentage of companies reporting the deficiency in this overall population. The he concluded twenty one classifications of internal control weaknesses. Widener (2004) designs a set of survey questions to measure management control. Van de Poel and Vanstraelen (2011) design a disclosure score of internal control. It includes nine items: the supervisory board discussed the internal control systems in at least one meeting, the purpose of control system, management's responsibilities for internal control, internal audit function, manage risk activities, audit committee, conduct code, accounting manual, whistleblower policy. It is better to measure internal control effectiveness completely using index system compared to dummy variable.

In short, the mandatory disclosures of internal control information provide more data for the empirical research regarding internal control weakness. However, there are some caveats. First, the usage of cross-sectional data may fail to consider the annual changes (Doyle et al. 2007a) and cause endogeneity problem (Ogneva et al. 2007; Hoitash et al. 2009; Johnstone et al. 2011). Cross-section may cause economy-wide effects of SOX to go undetected. Internal control bases on going-forward requirement, which might make companies change behaviours. That is, managers might improve the quality of internal control in order to benefit themselves because capital market participants would be informed well (Ogneva et al. 2007).

Second, it is hard to identify those companies did not disclose control problems, which influences the size of sample and the reliability of results (Doyle et al. 2007a; Naiker and Sharma 2009). It is difficult to control incentives of whether firms disclose or not. Some firms have internal control deficiencies but they do not discover or disclose them, which cannot be observed (Naiker and Sharma 2009). In fact, the choice to disclose and the actual present of weakness are two different things. This may cause the under-identification of true sample and influence the results. Moreover, the thresholds for materiality also differ in various firms. Modelling the materiality decision is needed in the future (Doyle et al. 2007a). Third, it is difficult to identify the exact time of deficiencies (Doyel et al. 2007b). In 
addition, logistic regression model may not test deeply the relation between dependent variables and independent variables. Better methods could be carried out to address these problems in future research.

\section{Potential Limitations and Future Research}

To summarize, there are several shortcomings existing in previous studies. First of all, in terms of research topics, the majority of researches are primarily restricted to American issues based on SOX. Only Van de Poel and Vanstraelen (2011) study Dutch setting. In fact, internal control regimes vary in different countries (Ve de Poel and Vanstraelen 2011). Control issues in other countries may be interesting and heterogeneous. Given special institutional background, traditional culture and regulations setting, we would find the different conclusions. For example, Chinese government is attempting to introduce and learn American internal control and corporate governance system, but differences still exist between China and the USA. Basic Standard for Enterprise Internal Control in China (2008) is called "China-SOX". Chinese internal control indeed has its special characteristics. "China-SOX" (2008) requires listed firms to disclose material weaknesses over both financial reporting and non-financial reporting. Issues about internal control in China would be worthy of further investigation. Future studies may also compare internal control problems in different countries. In addition, though some paper identifies the impact of size and industry in descriptive statistics. None of prior analyses focus on specific size and industry. SMEs, family or private enterprises, non-listed firms, bankruptcy firms and financial industry should have different control quality. For example, non-listed firms are not required to disclose internal control information; their internal control effectiveness may be different from listed firms. The research on bankruptcy firms is also scarce. There are mixed findings for the relation between firm size and control effectiveness. Further studies are needed in order to address the inconsistence. It is also interesting to study financial firms because their internal controls are generally considered better than other industries. Future research may study whether and why internal controls in financial industry are of good quality. Relative research regarding special sample firms is needed in the future.

Second, internal control studies rely on regulation background and provide evidence for debatable issues. However, some research is lack of strong theory base. Most paper bases on multi-stakeholder agency theory. On the one hand, decision rights are separated by some control mechanisms such as corporate governance and debt covenants. On the other hand, decision rights are joint by other mechanisms including internal and external auditing. Future studies might draw on other theories to further study internal control problems. For example, behavioral finance, management, economics, sociology, anthropology and psychology theory can fuel future research in this area.

Third, when it comes to research design, it is difficult to observe or verify internal control (Kinney 2000; Krishnan 2005). Internal control effectiveness should include both weak and good internal control. Good internal control contributes to positive outcome while weak internal control leads to negative results to some degree (Krishnan 2005). But majority of scholars only focus on internal control deficiency while ignore good internal control. Even some studies compare companies with weaknesses to that without, but without weaknesses may not represent good quality. For example, Wang (2010) defines strong internal control as the firms without material weakness. Non-material weakness does not equal to strong control, maybe there are still control deficiencies, significant deficiencies or just average control. It is better to measure internal control effectiveness from at least both positive and negative aspects even different levels. Internal control deficiencies mean ineffective internal controls while good internal controls stand for effective internal control. Majority alternative variables of internal control effectiveness include the improvement, weaknesses and audit opinion of internal control even accounting information quality. Using the disclosure of weaknesses to proxy for the actual control problem might result in systematic bias (Ge and McVay 2005; Doyle et.al. 2007b). The economic implication of variable design of internal control is not clear, which leads to the limitations of theoretical and practical significance of the study (Li 2009).

In term of the size of sample, smaller sample might influence the generalizability of the results (Krishnan 2005). Limited data may also make the results lack sufficient statistical power (Beneish et al. 2008). A larger sample size (all firms that disclose weaknesses) may results in more reliable results. For example, some studies use companies that without disclosing weaknesses as matched sample. By comparing two samples, they get more reliable results. However, small size may be not always unreliable and worse than large size. It is a reasonable way to control the incentive of firms that improve the effectiveness of internal control if we only choose the firms that are punished as sample. That is, if firms are punished, they are forced to remediate material weakness and improve the effectiveness of internal control. Furthermore, cross-sectional designs may lead to endogeneity, self-selection and omitted-variables (Ashbaurh et al. 2008). Also, firms may choose the quality of internal control and the effort of discovering and disclosing control deficiencies (Ashbaugh-Skaife et al. 2007), which may lead to self-selection problem. Lastly, most research uses short time frame, which makes it difficult to measure the influence of 
weaknesses disclosures. Long term data more than three years is also needed. It is better to compare the first few years of SOX and later periods because management and auditors may be more familiar with the process of internal control including implementation, evaluation and report (Doyle et al. 2007a). Particularly, there is no research takes advantage of recent data, for example, between 2010 and 2012. New data will be provided with the improvement of data gathering and measurement technology. Future research could take advantage of additional blended research methods such as survey, panel data, field research, case study, archival methods and experiment methods to reduce measurement errors. The recent and long term data is also needed in further study.

\section{Conclusions}

Since the implementation of SOX, the USA has entered the mandatory stage of internal control disclosure. Numerous researches focusing on the disclosure of internal control deficiencies were spurred. Prior research approached internal control deficiencies and their remediation from two dimensions. Horizontal dimensions study the relations between control problems or their remediation and internal or external factors such as corporate governance and stakeholders. Vertical dimensions examine specific-type weaknesses. Basic findings of previous literature show that economic incentives drive the disclosures of internal control deficiencies. Corporate governance and firm characterises influence the presence of control problems and weakness remediation. In turn, the weakness disclosures influence the quality of financing reporting, insider trading, the funders' giving decisions, the behaviours of auditors and debt contracting. Further, the failure of internal control leads to the improvement of corporate governance ( $\mathrm{Li}$ 2009). More internal control research combines with capital market and discusses that some regulations of SOX are not always effective. All in all, the findings makes contribute to practical issues by confirming that the disclosures of control deficiencies generally convey incremental information about the quality of financial reporting to investors.

There are three trends of research on internal control weakness. First, research objective changes from internal control deficiencies to information disclosures. Second, study perspective changes from internal characteristics of firms to external factors of companies. Third, research approach changes from firm level to capital market (Bai and Gao 2011). An analysis framework is inferred from these trends. It is comprised of determinants (affecting factors and corporate governance) and economic consequences (accruals quality, market reaction, cost of equity and debt contracting) of weakness disclosure and its remediation. Future research might further address some issues by utilizing new views, theories, methods and samples. Comparative research that analyzes the similarities or differences in various settings would be of interest.

\section{References}

Ashbaugh-Skaife, H., D. Collins, \& W. Kinney. (2007). The discovery and reporting of internal control deficiencies prior to SOX-mandated audits. Journal of Accounting and Economics, 44, 166-192. https://doi.org/10.1016/j.jacceco.2006.10.001

Ashbaugh-Skaife, H., D. Collins, W. Kinney \& R. LaFond. (2009). The effect of internal control deficiencies on firm risk and cost of equity capital. Journal of Accounting Research, 47, 1-43. https://doi.org/10.1111/j.1475-679X.2008.00315.x

Ashbaugh-Skaife, H., D. Collins, W. Kinney \& R. LaFond. (2008). The effect of SOX internal control deficiencies and their remediation on accrual quality. The Accounting Review, 83, 217-250. https://doi.org/10.2308/accr.2008.83.1.217

Bai Huai \& Gao Li. (2011). The new trend of empirical research on internal control deficiencies: a review of the literature. Communication of Finance and Accounting, 5, 111-114.

Bedard, J., R. Hoitash, U. Hoitash \& K. Westermann. (2012). Material weakness remediation and earnings quality: A detailed examination by type of control deficiency. Forthcoming Auditing: A Journal of Practice \& Theory (SSRN).

Beneish, M., M. Billings \& L. Hodder. (2008). Internal control weaknesses and information uncertainty. The Accounting Review, 83, 665-703. https://doi.org/10.2308/accr.2008.83.3.665

Bodnar.G. (1975). Reliability modeling of internal control systems. The Accounting Review, 10, 747-757.

Bronson N. Scott, Carcello V. Joseph, \& Raghunandan K. (2006). Firm characteristics and voluntary management reports on internal control. Auditing: A Journal of Practice \& Theory, 25(2), November, 25-39. https://doi.org/10.2308/aud.2006.25.2.25

Burrows Ashley. (2011). 10 years after Enron. Chartered Accountants Journal, 12, 60-62. 
Calderon G. Thomas, Wang Li, \& Conrad J. Edward. (2012). Material internal control weakness reporting since the Sarbanes-Oxley Act. The CPA Journal, 8, 20-25.

Carcello, J. V., \& Neal.T. L. (2003). Audit committee characteristics and auditor dismissals following "new" going-concern reports. The Accounting Review, 78 (January)9, 5-117.

Cassar Gavin \& Joseph Gerakos. (2010). Determinants of hedge fund internal controls and fees. The Accounting Review, 85(6), 1887-1919.

Costello, A. \& R. Wittenberg-Moerman. (2011). The impact of financial reporting quality on debt contracting: Evidence from internal control weakness reports. Journal of Accounting Research, 49, 97-136. https://doi.org/10.1111/j.1475-679X.2010.00388.x

DeFond M.L., Hann R., Hu X. (2005). Does the market value financial expertise on audit committees of boards of directors? Journal of Accounting Research, 43(2), 269-312. https://doi.org/10.1111/j.1475-679x.2005.00166.x

Dan Dhaliwal, Chris Hogan, Robert Trezevant, Michael Wilkins. (2011). Internal control disclosures, monitoring, and the cost of debt. The Accounting Review, 86(4), 1131- 1156. https://doi.org/10.2308/accr-10043

Doyle, J., W. Ge, \& McVay. S. (2007a). Determinants of weaknesses in internal control over financial reporting. Journal of Accounting and Economics, 44, 193-223. https://doi.org/10.1016/j.jacceco.2006.10.003

Doyle, J., W. Ge, \& McVay. S. (2007b). Accruals quality and internal control over financial reporting. The Accounting Review, 82, 1141-1170. https://doi.org/10.2308/accr.2007.82.5.1141

Ettredge Michael L., Li Chan, \& Sun Lili. (2006). The Impact of SOX Section 404 Internal Control Quality Assessment on Audit Delay in the SOX Era. Auditing: A Journal of Practice \& Theory, 25(2), November, 1-23. https://doi.org/10.2308/aud.2006.25.2.1

Feng Mei, Li Chan, McVay Sarah. (2009). Internal control and management guidance. Journal of Accounting and Economics, 48, 190-209. https://doi.org/10.1016/j.jacceco.2009.09.004

Ge, W., \& S. McVay. (2005). The disclosure of material weaknesses in internal control after the Sarbanes-Oxley Act. Accounting Horizons, 19, 137-158. https://doi.org/10.2308/acch.2005.19.3.137

Goh Wee Beng \& Li Dan. (2011). Internal controls and conditional conservatism. The Accounting Review, 86(3), 975-1005. https://doi.org/10.2308/accr.00000041

Hammersley, J., Myers, L. \& Shakespeare. C. (2008). Market reactions to the disclosure of internal control weaknesses and to the characteristics of those weaknesses under Section 302 of the Sarbanes-Oxley Act of 2002. Review of Accounting Studies, 13, 141- 165.

Hmtden. Susan S. (1980). A chance-constrained mixed integer programming model for internal control design. The Accounting Review, 4(10), 578-593.

Hoitash, Rani, Hoitash, Udi, \& Bedard, Jean C. (2008). Internal Control Quality and Audit Pricing under the Sarbanes-Oxley Act. Auditing: A Journal of Practice \& Theory, 27(1), May 105-126. https://doi.org/10.2308/aud.2008.27.1.105

Hoitash, R., Hoitash U. \& Bedard, J. (2009). Corporate governance and internal control over financial reporting: A comparison of regulatory regimes. The Accounting Review, 84, 839-867. https://doi.org/10.2308/accr.2009.84.3.839

Hogan and Wilkins. 2008. Evidence on the Audit Risk Model: Do Auditors Increase Audit Fees in the Presence of Internal Control Deficiencies? Contemporary Accounting Research Vol. 25 No. 1: 219-242. https://doi.org/10.1506/car.25.1.9

Kim Yongtae, Park Myung Seok. (2009). Market uncertainty and disclosure of internal control deficiencies under the Sarbanes-Oxley Act. J. Account. Public Policy, 28, 419- 445. https://doi.org/10.1016/j.jaccpubpol.2009.07.004

Kim, J.-B., Song, B. \& Zhang. L. (2010). Internal control weakness and bank loan contracting: Evidence from SOX Section 404 disclosures. The Accounting Review, Forthcoming.

Kinney, W. (2000). Research opportunities in internal control quality and quality assurance. Auditing: A Journal of Practice \& Theory, (19), 83-90.

Krishnan, J. (2005). Audit committee quality and internal control: An empirical analysis. The Accounting Review, 80, 649-675. https://doi.org/10.2308/accr.2005.80.2.649 
Johnstone, K., C. Li \& Rupley. K. (2011). Changes in corporate governance associated with the revelation of internal control material weaknesses and their subsequent remediation. Contemporary Accounting Research, 28, 331-383. https://doi.org/10.1111/j.1911-3846.2010.01037.x

Larcker, D. F., Richardson, S. A. \& Tuna. S. I. (2007). Corporate governance, accounting outcomes, and organizational performance. The Accounting Review, 82(4), 963-1008. https://doi.org/10.2308/accr.2007.82.4.963

Leone J. Andrew. (2007). Factors related to internal control disclosure: A discussion of Ashbaugh, Collins, and Kinney (2007) and Doyle, Ge, and McVay (2007). Journal of Accounting and Economics, 44, 224-237. https://doi.org/10.1016/j.jacceco.2007.01.002

Li Chan, Sun Lili, Ettredge Michael. (2010). Financial executive quality, financial executive turnover, and adverse SOX 404 opinions. Journal of Accounting and Economics, 50(1), 93-110. https://doi.org/10.1016/j.jacceco.2010.01.003

Li Xiang. (2009). USA empirical internal control research: literature review and implications. Audit Research, (6), 87-95.

Lin Shu, Pizzini Mina, Vargus Mark, Bardhan R. Indranil. (2011). The role of the internal audit function in the disclosure of material weaknesses. The Accounting Review, 86(1), 287-323. https://doi.org/10.2308/accr.00000016

Lopez J. Thomas, Vandervelde D. Scott, Wu Yi-Jing. (2009). Investor perceptions of an auditor's adverse internal control opinion. J. Account. Public Policy, 28, 231-250. https://doi.org/10.1016/j.jaccpubpol.2009.04.003

Masli Adi, Peters F. Gary, Richardson J. Vernon, Sanchez Juan Manuel. (2010). Examining the potential benefits of internal control monitoring technology. The Accounting Review, 85(3), 1001-1034. https://doi.org/10.2308/accr.2010.85.3.1001

Munsif Vishal, Raghunandan K., \& Rama V.Dasaratha. (2012). Internal control reporting and audit report lags: further evidence. Auditing: A Journal of Practice \& Theory, 31, 3(8), 203-218.

Naiker, V. \& Sharma.D. (2009). Former audit partners on the audit committee and internal control deficiencies. The Accounting Review, 84(2), 559-587. https://doi.org/10.2308/accr.2009.84.2.559

Ogneva, M., Raghunandan K. \& Subramanyam. K. (2007). Internal control weakness and cost of equity: Evidence from SOX Section 404 certifications. The Accounting Review, 82, 1255-1297. https://doi.org/10.2308/accr.2007.82.5.1255

Petrovits Christine, Shakespeare Catherine \& Shih Aimee. (2011). The causes and consequences of internal control problems in non-profit organizations. The Accounting Review, 86(1), 325-357. https://doi.org/10.2308/accr.00000012

Public Company Accounting Oversight Board. (2004). Auditing Standard No. 2, An Audit of Internal Control over Financial Reporting Performed in Conjunction with An Audit of Financial Statements, PCAOB, March 9.

Rice, S. \& Weber. D. (2012). How effective is internal control reporting under SOX 404? Determinants of the (Non-) disclosure of existing material weaknesses. Journal of Accounting Research, 50(3), 811-843. https://doi.org/10.1111/j.1475-679X.2011.00434.X

Rose M. Jacob, Norman Strand Carolyn, Rose M. Anna. (2010). Perceptions of investment risk associated with material control weakness pervasiveness and disclosure detail. The Accounting Review, 85(5), 1787-1807. https://doi.org/10.2308/accr.2010.85.5.1787

Schneider Arnold, Church K Bryan. (2008). The effect of auditors' internal control opinions on loan decisions. Journal of Accounting and Public Policy, 27, 1-18. https://doi.org/10.1016/j.jaccpubpol.2007.11.004

Skaife A. Hollis, Veenman David, Wangerin Daniel. (2012). Internal control over financial reporting and managerial rent extraction: Evidence from the profitability of insider trading. Journal of Accounting and Economics, 7 , $2-20$.

Srinivasan, S. (2005). Consequences of financial reporting failure for outside directors: Evidence from accounting restatements and audit committee members. Journal of Accounting Research, 43, 291-334. https://doi.org/10.1111/j.1475-679x.2005.00172.x 
Van de Poel Katrien \& Vanstraelen Ann. (2011). Management reporting on internal control and accruals quality: insights from a "Comply-or-Explain" Internal Control Regime. Auditing: A Journal of Practice \& Theory, 30, 3(8), 181-209.

Wang Xue. (2010). Increased disclosure requirements and corporate governance decisions: Evidence from chief financial officers in the pre- and post-Sarbanes-Oxley periods. Journal of Accounting Research, 48(4), September 885-920.

Widener. K. Sally. (2004). An empirical investigation of the relation between the use of strategic human capital and the design of the management control system. Accounting, Organizations and Society, (29), 377-399.

Zhang, Y., Zhou, J. \& Zhou. N. (2007). Audit committee quality, auditor independence, and internal control weaknesses. Journal of Accounting and Public Policy, 26, 300-327. https://doi.org/10.1016/j.jaccpubpol.2007.03.001

\section{Notes}

Note 1. The Accounting Review, Journal of Accounting and Economics, Journal of Accounting Research, Contemporary Accounting Research, Auditing: A Journal of Practice \& Theory, Accounting Horizons, Journal of Accounting and Public Policy, Review of Accounting Studies.

Note 2. One of the objectives of corporate governance is that the board remains in effective control of the affairs of the company at all times.

Note 3. They include Accounting documentation policy and/or procedures, Material and/or numerous auditor year end. "Adjustments, Accounting personnel resources (competency, training), Restatement or non-reliance of company filings, Untimely or inadequate account reconciliations, Information technology (software, security, access issues), Non-routine transactions control issues, Segregation of duties, design of controls, Restatement of previous 404 disclosures, Journal entry control issues, Senior management (competency, tone, and reliability issues), Ethical or compliance issues with personnel, Scope (disclaimer of opinion or other limitations), Management, board, or audit committee investigations, Insufficient or non-existent internal audit function, Ineffective or understaffed audit committee, Ineffective regulatory compliance issues, SEC or other regulatory investigations and/or Inquiries, Inadequate disclosure controls (timely, accuracy, and complete), SAB 108 adjustment issues and Remediation from material weakness identified". 


\section{Appendix}

Table 1. Determinants of internal control weakness

\begin{tabular}{llllll}
\hline Issue & Studies & Setting & Period & Sample Size & Results \\
\hline Material & Ge and & SOX & August & 261 & The disclosure of material weakness is positively \\
weakness & McVay & 302 & 2002 to & & $\begin{array}{l}\text { related with business complexity, negatively linked } \\
\text { with firm size and profit. }\end{array}$ \\
disclosure & (AH & & $\begin{array}{l}\text { November } \\
\text { 2005) }\end{array}$ & &
\end{tabular}

Determinants

of internal

Doyle

of inte

control

weakness
779

August

2002 to

$\begin{array}{lll}2007 a) & \text { SOX } & 2002 \\ & & \end{array}$

(1)

\begin{tabular}{|c|c|c|c|c|}
\hline $\begin{array}{l}\text { Economic } \\
\text { factors that } \\
\text { firms } \\
\text { discover and } \\
\text { report } \\
\text { internal } \\
\text { control } \\
\text { weakness }\end{array}$ & $\begin{array}{l}\text { Ashbaugh } \\
\text { et al. } \\
\text { (JAE } \\
\text { 2007) }\end{array}$ & $\begin{array}{l}\text { SOX } \\
302\end{array}$ & $\begin{array}{l}\text { November } \\
2003 \text { to } \\
\text { December } \\
2004\end{array}$ & 326 \\
\hline $\begin{array}{l}\text { Determinants } \\
\text { of the } \\
\text { disclosure of } \\
\text { material } \\
\text { weakness }\end{array}$ & $\begin{array}{l}\text { Rice et al. } \\
\text { (JAR } \\
2012)\end{array}$ & $\begin{array}{l}\text { SOX } \\
404\end{array}$ & 2009 & 488 \\
\hline $\begin{array}{l}\text { The } \\
\text { qualifications } \\
\text { and turnover } \\
\text { of CFO and } \\
\text { unqualified } \\
\text { audit } \\
\text { opinions }\end{array}$ & $\begin{array}{l}\mathrm{Li} \text { et al. } \\
(\mathrm{JAE} \\
2010)\end{array}$ & $\begin{array}{l}\text { SOX } \\
404\end{array}$ & 2004 & 2478 \\
\hline $\begin{array}{l}\text { Internal } \\
\text { control and } \\
\text { monitoring } \\
\text { technology }\end{array}$ & $\begin{array}{l}\text { Masli et } \\
\text { al. (AR } \\
2010)\end{array}$ & $\begin{array}{l}\text { SOX } \\
404\end{array}$ & 2003-2006 & 152 \\
\hline $\begin{array}{l}\text { Causes of } \\
\text { control } \\
\text { problems in } \\
\text { non-profit } \\
\text { organizations }\end{array}$ & $\begin{array}{l}\text { Petrovits } \\
\text { et al. (AR } \\
\text { 2011) }\end{array}$ & & 1999-2007 & 27495 \\
\hline $\begin{array}{l}\text { Determinants } \\
\text { of hedge } \\
\text { fund internal } \\
\text { controls and } \\
\text { fees }\end{array}$ & $\begin{array}{l}\text { Cassar } \\
\text { and } \\
\text { Gerakos } \\
\text { (AR } \\
2010)\end{array}$ & & 2003-2007 & 358 \\
\hline
\end{tabular}

They confirm the findings of Ge and McVay (2005) but complement that young age, rapid growth and restructure are consistently positively related weaknesses. More severe entity-wide issues are more pervasive in young, small and weaker financial companies, while less serious account-specific issues exist in healthy financial, diversified complex, and rapidly changing firms. Firms with staff-related problems tend to be financially weak and smaller, while firms with complexity-related problems have complex, diversified and rapidly changing operations. The findings imply that imposing restrictions are ineffective.

Fewer resources, organizational changes, accounting risk, auditor resignations and complex operations are positively associated with the disclosure of internal control deficiencies. The incentives of discovering and reporting control problems are usually relative to concentrated institutional ownership, prior SEC enforcement actions, audited by a dominant accounting firm and financial restatements.

Size, external capital, being audited by a large accounting firm, less auditor effort, non-audit fees, less financial distress, less changes of auditor and management, less reported material weaknesses and restatements are positively related with higher probability of disclosing control problems.

Less qualified CFOs (whether he or she has a CPA license or has worked in a pubic audit firm, how many years he or she worked as a $\mathrm{CFO}$ ) and more CFO turnover are more likely related with adverse SOX 404 opinions.

They find that there is a negative relation between the implementation of monitoring technology and material weaknesses.

Poor financial health, more growth, more complexity and smaller size are related with control problems.

The results show that high potential agency costs, managers of funds domiciled offshore, levered and young funds are related to strong internal control. The findings also indicate that there is a positive relation between internal control quality and performance fee rewarded to managers. This suggests that internal controls seem less likely to detect or prevent earnings management of managers. 
Table 2. Internal control weakness and corporate governance

\begin{tabular}{|c|c|c|c|c|c|}
\hline Issue & Studies & Setting & Period & Sample Size & Results \\
\hline $\begin{array}{l}\text { Audit } \\
\text { committee } \\
\text { quality and } \\
\text { internal } \\
\text { control }\end{array}$ & $\begin{array}{l}\text { Krishnan } \\
\text { (AR } \\
2005 \text { ) }\end{array}$ & $\begin{array}{l}\text { SOX } \\
302 \\
\text { and } \\
404\end{array}$ & 1994-2002 & 128 & $\begin{array}{l}\text { Independence and the numbers of financial } \\
\text { expertise of audit committees are significantly } \\
\text { negatively related with both levels of internal } \\
\text { control problems (less severe reportable } \\
\text { conditions and more severe material weaknesses). } \\
\text { Auditor tenure, financial stress, CFO, CAO or } \\
\text { Controller' job experience and tendency to engage } \\
\text { in fraud are linked with the incidence of control } \\
\text { problems. Board of directors, the internal audit } \\
\text { function and the external auditor are not found to } \\
\text { be associated with control problems. }\end{array}$ \\
\hline
\end{tabular}

\begin{tabular}{|c|c|c|c|c|c|}
\hline $\begin{array}{l}\text { Audit } \\
\text { committee } \\
\text { quality, } \\
\text { auditor } \\
\text { independence } \\
\text { and control }\end{array}$ & $\begin{array}{l}\text { Zhang et } \\
\text { al. (JAPP } \\
\text { 2007) }\end{array}$ & $\begin{array}{l}\text { After } \\
\text { SOX }\end{array}$ & $\begin{array}{l}\text { November } \\
15,2004 \text { to } \\
\text { July } \\
31,2005\end{array}$ & 208 & $\begin{array}{l}\text { The disclosure of material weakness is positively } \\
\text { related with less audit committee financial } \\
\text { expertise, especially less accounting financial } \\
\text { expertise and non-accounting financial expertise. } \\
\text { Material weakness disclosure is positively with } \\
\text { auditor changes and auditor independence. }\end{array}$ \\
\hline
\end{tabular}

$\begin{array}{lllll}\text { Corporate } & \text { Hoitash et } & \text { SOX } & \text { November } 5480 \\ \text { governance } & \text { al. (AR } & 302 & 2004 \text { to } & \\ \text { and internal } & \text { 2009) } & \text { and } & \text { May 2006 } & \\ \text { control } & & 404 & \end{array}$

\begin{tabular}{|c|c|c|c|c|c|}
\hline $\begin{array}{l}\text { Audit } \\
\text { committee } \\
\text { members and } \\
\text { accounting } \\
\text { restatements }\end{array}$ & $\begin{array}{l}\text { Srinivasan } \\
\text { (JAR } \\
2005)\end{array}$ & & $\begin{array}{l}1997 \\
2001\end{array}$ & to & 409 \\
\hline $\begin{array}{l}\text { Changes in } \\
\text { corporate } \\
\text { governance } \\
\text { and material } \\
\text { weaknesses }\end{array}$ & $\begin{array}{l}\text { Johnstone } \\
\text { et al. } \\
\begin{array}{l}\text { (CAR } \\
2011)\end{array}\end{array}$ & $\begin{array}{l}\text { SOX } \\
404\end{array}$ & $\begin{array}{l}2004 \\
2007\end{array}$ & to & 3602 \\
\hline $\begin{array}{l}\text { Former audit } \\
\text { partners on } \\
\text { the audit } \\
\text { committee } \\
\text { and control } \\
\text { deficiencies }\end{array}$ & $\begin{array}{l}\text { Naiker } \\
\text { and } \\
\text { Sharma } \\
\text { (AR } \\
2009 \text { ) }\end{array}$ & $\begin{array}{l}\text { SOX } \\
404\end{array}$ & 2004 & & 1225 \\
\hline
\end{tabular}

Less audit committee members with accounting and supervisory experience and board strength, delegating financial experts without accounting experience or multiple financial experts as audit committee members all lead to material weakness. Only accounting financial experts are related with the disclosure of account -specific control issues, while only supervisory financial experts are linked with the disclosure of management-oriented problems on personnel and information technology. Both accounting and supervisory expertise are related with better internal controls, while "user" financial experts are found to related with more material weakness disclosure. However, all relationships are only detectable under SOX 404 rather than SOX 302.

Outside directors bear reputational costs when their companies report income-decreasing restatements. Further, higher turnover of boards especially audit committee links to more technical restatements.

Positive associations are found between internal control material weakness and turnover of audit committees, board of directors and top management.

There is a negative association between AFAPs and UFAPs and internal control material weakness. 


\begin{tabular}{|c|c|c|c|c|c|}
\hline $\begin{array}{l}\text { Internal } \\
\text { control and } \\
\text { insider } \\
\text { trading }\end{array}$ & $\begin{array}{l}\text { Skaife et } \\
\text { al. (JAE } \\
\text { 2012) }\end{array}$ & $\begin{array}{l}\text { SOX } \\
404\end{array}$ & $2004-2008$ & 4505 & $\begin{array}{l}\text { The results show that there is no relationship } \\
\text { between insider trading and weakness } \\
\text { remediation. }\end{array}$ \\
\hline $\begin{array}{l}\text { Control } \\
\text { disclosure } \\
\text { and corporate } \\
\text { governance }\end{array}$ & $\begin{array}{l}\text { Wang et } \\
\text { al. (JAR } \\
2010)\end{array}$ & $\begin{array}{l}\text { Before } \\
\text { and } \\
\text { after } \\
\text { SOX }\end{array}$ & $\begin{array}{l}1998- \\
2005\end{array}$ & 27797 & $\begin{array}{l}\text { The results show that weak control result in lower } \\
\text { compensation and higher turnover of CFOs after } \\
\text { SOX. While strong control leads to higher } \\
\text { compensation and insignificant changes of } \\
\text { turnover of CFOs. This suggests that mandatory } \\
\text { disclosures distinguish effectively good and bad } \\
\text { CFOs and reduce information asymmetry in the } \\
\text { executive labor market. }\end{array}$ \\
\hline $\begin{array}{l}\text { Internal audit } \\
\text { and material } \\
\text { weakness }\end{array}$ & $\begin{array}{l}\text { Lin et al. } \\
\text { (AR } \\
2011)\end{array}$ & $\begin{array}{l}\text { SOX } \\
404\end{array}$ & 2003-2004 & 214 & $\begin{array}{l}\text { They find that there is a negative relation between } \\
\text { material weakness and the education level, the } \\
\text { extent of internal audit includes quality assurance } \\
\text { techniques into fieldwork, audit activities } \\
\text { associated with financial reports and monitoring } \\
\text { of weakness remediation. The quality of internal } \\
\text { auditing prevents the incidence of material } \\
\text { weaknesses. They also find that there is a positive } \\
\text { relation between material weakness and internal } \\
\text { auditing of grading auditing engagement and } \\
\text { external coordination of internal auditor, which } \\
\text { improves internal control effectiveness. }\end{array}$ \\
\hline
\end{tabular}


Table 3. Internal control weakness and accruals quality

\begin{tabular}{|c|c|c|c|c|c|}
\hline Issue & Studies & Setting & Period & Sample Size & Results \\
\hline $\begin{array}{l}\text { Internal } \\
\text { control } \\
\text { environment } \\
\text { and accruals } \\
\text { quality }\end{array}$ & $\begin{array}{l}\text { Doyle et al. } \\
\text { (AR } \\
2007 \mathrm{~b})\end{array}$ & $\begin{array}{l}\text { SOX } \\
302 \\
\text { and } \\
404\end{array}$ & $\begin{array}{l}\text { August } \\
2002 \text { to } \\
\text { November } \\
2005\end{array}$ & 705 & $\begin{array}{l}\text { Only SOX } 302 \text { disclosures appear to be linked with } \\
\text { poorer earnings quality compared to SOX } 404 \text { on } \\
\text { average. Only overall company-specific problems } \\
\text { (versus account level) drive strongly low accruals } \\
\text { quality for both SOX } 302 \text { and } 404 \text {. They find no } \\
\text { differences in earning quality for material weakness } \\
\text { under SOX } 404 \text { regardless of whether the firms } \\
\text { disclose deficiencies or not. }\end{array}$ \\
\hline $\begin{array}{l}\text { Internal } \\
\text { control } \\
\text { deficiencies } \\
\text { and accruals } \\
\text { quality }\end{array}$ & $\begin{array}{l}\text { Ashbaugh } \\
\text { et al. (AR } \\
\text { 2008) }\end{array}$ & $\begin{array}{l}\text { SOX } \\
404\end{array}$ & $2003-2005$ & 1281 & $\begin{array}{l}\text { The presence of control deficiencies result in more } \\
\text { reliable financial reporting measured as low-quality } \\
\text { accruals by reducing unintentional and intentional } \\
\text { misstatements. Further, a causal association between } \\
\text { internal control effectiveness and accrual quality is } \\
\text { found in successive years. }\end{array}$ \\
\hline $\begin{array}{l}\text { Internal } \\
\text { control and } \\
\text { accruals } \\
\text { quality }\end{array}$ & $\begin{array}{l}\text { Van de } \\
\text { Poel and } \\
\text { Vanstraelen } \\
(2011)\end{array}$ & Dutch & 2004-2005 & 171 & $\begin{array}{l}\text { They find that the description of internal control } \\
\text { system is not related with the provision of accruals } \\
\text { quality information. But effective internal control is } \\
\text { positively related with accruals. They also find that } \\
\text { few firms disclose management statement on internal } \\
\text { control. Their findings contribute to the debate on } \\
\text { internal control regulation based on global regime. }\end{array}$ \\
\hline $\begin{array}{l}\text { Internal } \\
\text { control and } \\
\text { management } \\
\text { guidance }\end{array}$ & $\begin{array}{l}\text { Feng et al. } \\
\text { (JAE 2009) }\end{array}$ & $\begin{array}{l}\text { SOX } \\
404\end{array}$ & 2004-2006 & 2994 & $\begin{array}{l}\text { Control problems not only influence earning quality, } \\
\text { but also result in less accurate management guidance. }\end{array}$ \\
\hline $\begin{array}{l}\text { Internal } \\
\text { control and } \\
\text { conservatism }\end{array}$ & $\begin{array}{l}\text { Goh and } \mathrm{Li} \\
\text { (AR 2011) }\end{array}$ & $\begin{array}{l}\text { SOX } \\
302 \\
\text { and } \\
404\end{array}$ & $\begin{array}{lr}\text { Jan } & 2003 \\
\text { to } & \text { Nov } \\
2005 & \end{array}$ & 1146 & $\begin{array}{l}\text { The results show that internal control quality is } \\
\text { positively related with conservatism. In particular, } \\
\text { material weaknesses result in lower conservatism. } \\
\text { The findings suggest that strong internal control } \\
\text { facilitate conservatism. }\end{array}$ \\
\hline
\end{tabular}


Table 4. Control deficiencies and auditing process

\begin{tabular}{|c|c|c|c|c|c|}
\hline Issue & Studies & Setting & Period & Sample Size & Results \\
\hline $\begin{array}{l}\text { Control } \\
\text { deficiencies } \\
\text { and audit } \\
\text { fees }\end{array}$ & $\begin{array}{l}\text { Hogan } \\
\text { and } \\
\text { Wilkins } \\
\text { (CAR } \\
\text { 2008) }\end{array}$ & $\begin{array}{l}\text { SOX } \\
302\end{array}$ & $\begin{array}{l}\text { November } \\
1, \quad 2003 \\
\text { and } \\
\text { November } \\
30,2004\end{array}$ & 284 & $\begin{array}{l}\text { They find that audit fees are high significantly for firms that } \\
\text { disclosed control deficiencies. Particularly, audit fees are } \\
\text { highest for material weaknesses. As audit fees may proxy for } \\
\text { audit effort to some extent, they also find that auditor increase } \\
\text { the efforts when control deficiencies exist. Additional analysis } \\
\text { shows that audit fees are higher for control deficiencies no } \\
\text { matter whether they are audited by Big } 4 \text {. Further, audit fees } \\
\text { are high for control deficiencies firms with auditors for one or } \\
\text { second year compared to longer tenure. This suggests that } \\
\text { auditor type and tenure influence auditor responses to control } \\
\text { deficiencies. }\end{array}$ \\
\hline
\end{tabular}

$\begin{array}{llll}\text { Internal } & \text { Hoitash } & \text { SOX } & \text { November } 2501 \\ \text { control } & \text { et al. (A } & 404 & 2004 \text { to } \\ \text { quality and } & \text { 2007) } & \text { and } & \text { October } \\ \text { audit } & & 302 & 2005 \\ \text { pricing } & & & \end{array}$

$\begin{array}{lllll}\text { Control } & \text { Ettredge } & \text { SOX } & \text { January } 2344 \\ \text { quality } & \text { et al. } & 404 & 2005 \text { to } & \\ \text { assessment } & \text { (JAR } & & \text { June } & \\ \text { and audit } & \text { 2009) } & & 2005 & \\ \text { delay } & & & \end{array}$

$\begin{array}{llllll}\text { Internal } & \text { Munsif } & \text { SOX } & 2008 & \text { to } 2839 \\ \text { control and } & \text { et al. } & 404 & 2009 & & \\ \text { audit lag } & (2012) & & & & \end{array}$

They find that audit pricing for companies with internal control problems varies by problem severity, when severity is measured either as material weaknesses versus significant deficiencies, or by nature of the problem. Also, while audit fees increase during the 404 period, the tests show less relative risk adjustment under Section 404 than under Section 302 in the prior year. Further examining intertemporal effects, they find that companies disclosing internal control problems under Section 302 continue

to pay higher fees the following year, even if no problems are disclosed under Section 404. Overall, their findings provide detailed insight into audit risk adjustment during the initial period of SOX implementation.

The results indicate that material weakness is linked with longer audit delays. Specially, general material weakness is related with longer delays than specific problems. The problems such as personnel, process and procedure, segregation of duties and closing process are associated with longer audit delays. Overall, they provide evidence that SOX 404 assessments are significantly related with long audit delay. The findings suggest that it is hard for firms to shorten deadlines of 10-K filings according to the desire of SEC under SOX 404. This supports the decisions of SEC that to defer for one year for large and accelerated filers of 10-K filing.

The results show that audit lag in the presence of control weaknesses increase lowly for non-accelerated in 2008. But the impact of control deficiencies on audit lag is lower for accelerated filers in 2009. The results also indicate that the small accelerated filers are smaller to other accelerated filers and different from non-accelerated for auditors in terms of the relation between audit lag and control deficiencies. Overall, they offer evidence on the extent of audit effort related to control deficiencies. The evidence suggests that accelerated and non-accelerated companies are quite different on auditor services. 
Table 5. Market reactions to weakness disclosures

\begin{tabular}{|c|c|c|c|c|c|}
\hline Issue & Studies & Setting & Period & Sample Size & Results \\
\hline $\begin{array}{l}\text { Market } \\
\text { reactions to } \\
\text { financial } \\
\text { expertise } \\
\text { on audit } \\
\text { committees }\end{array}$ & $\begin{array}{l}\text { Defond et } \\
\text { al. (JAR } \\
2005)\end{array}$ & $\begin{array}{l}\text { Before } \\
\text { SOX }\end{array}$ & $1993-2002$ & 702 & $\begin{array}{l}\text { The market reacts favourably to the appointment of } \\
\text { accounting financial experts, but there is no reaction to } \\
\text { non-accounting financial experts. Positive reaction is } \\
\text { concentrated only when corporate governance is } \\
\text { relatively strong. }\end{array}$ \\
\hline $\begin{array}{l}\text { Stock price } \\
\text { reactions to } \\
\text { weaknesses } \\
\text { disclosure }\end{array}$ & $\begin{array}{l}\text { Hammersley } \\
\text { et al. (RAS } \\
\text { 2008) }\end{array}$ & $\begin{array}{l}\text { SOX } \\
302\end{array}$ & $\begin{array}{l}\text { November } \\
2003 \text { to } \\
\text { January } \\
2005\end{array}$ & 613 & $\begin{array}{l}\text { Severity, auditability, management's conclusion on the } \\
\text { effectiveness and vagueness of the disclosures are } \\
\text { informative. Information contents of weaknesses } \\
\text { disclosures vary on the severity of the weaknesses. The } \\
\text { negative price reactions to the disclosure of control } \\
\text { weaknesses are generated in a clear sub-sample. }\end{array}$ \\
\hline $\begin{array}{l}\text { Capital } \\
\text { market } \\
\text { reactions to } \\
\text { weakness } \\
\text { disclosures }\end{array}$ & $\begin{array}{l}\text { Beneish et } \\
\text { al. } \quad \text { (AR } \\
2008)\end{array}$ & $\begin{array}{l}\text { SOX } \\
302 \\
\text { and } \\
404\end{array}$ & 2004-2005 & 330 & $\begin{array}{l}\text { Disclosures under SOX } 302 \text { have noticeably negative } \\
\text { abnormal returns. In contrary, the firms making SOX } \\
404 \text { disclosures experience no significant stock price. }\end{array}$ \\
\hline $\begin{array}{l}\text { Market } \\
\text { uncertainty } \\
\text { and } \\
\text { control } \\
\text { deficiencies }\end{array}$ & $\begin{array}{l}\text { Kim and } \\
\text { Park (JAPP } \\
\text { 2009) }\end{array}$ & $\begin{array}{l}\text { SOX } \\
302\end{array}$ & 2004 & 608 & $\begin{array}{l}\text { They find that abnormal stock returns negatively relate } \\
\text { with the changes of market uncertainty when control } \\
\text { deficiencies are disclosed. They also find that reduced } \\
\text { uncertainty has greater influence on voluntary } \\
\text { disclosures of non-material weaknesses. }\end{array}$ \\
\hline $\begin{array}{l}\text { Risk } \\
\text { perceptions } \\
\text { and } \\
\text { material } \\
\text { weaknesses }\end{array}$ & $\begin{array}{l}\text { Rose et al. } \\
\text { (AR 2010) }\end{array}$ & $\begin{array}{l}\text { SOX } \\
404\end{array}$ & & 97 & $\begin{array}{l}\text { The results of experiments indicate that the disclosures } \\
\text { of material weaknesses and the details of the } \\
\text { pervasiveness of material weaknesses make investors } \\
\text { adjust risk assessment. The findings also show that } \\
\text { material weaknesses pervasiveness and disclosure } \\
\text { detail are interactive. Investors increase risk assessment } \\
\text { when material weaknesses are not pervasive and } \\
\text { include both specific and detained disclosures. This } \\
\text { suggests that various levels of management investor } \\
\text { trust drive the results. }\end{array}$ \\
\hline
\end{tabular}

Table 6. Cost of capital and weakness disclosures

\begin{tabular}{|c|c|c|c|c|c|}
\hline Issue & Studies & Setting & Period & Sample Size & Results \\
\hline $\begin{array}{l}\text { Internal } \\
\text { control } \\
\text { weaknesses } \\
\text { and } \\
\text { information } \\
\text { uncertainty }\end{array}$ & $\begin{array}{l}\text { Beneish } \\
\text { et al. (AR } \\
\text { 2008) }\end{array}$ & $\begin{array}{l}\text { SOX } \\
302 \\
\text { and } \\
404\end{array}$ & 1993-2002 & 702 & $\begin{array}{l}\text { High implied cost of capital associated with SOX } 302 \\
\text { disclosures. However, they fail to find evidence that } \\
\text { cost of equity is impacted by the disclosures of SOX } \\
404 \text {. }\end{array}$ \\
\hline $\begin{array}{l}\text { Cost of } \\
\text { equity and } \\
\text { internal } \\
\text { control } \\
\text { weakness }\end{array}$ & $\begin{array}{l}\text { Ogneva } \\
\text { et al. (AR } \\
\text { 2007) }\end{array}$ & $\begin{array}{l}\text { SOX } \\
404\end{array}$ & $\begin{array}{l}\text { November } \\
2004 \text { to } \\
\text { January } \\
2009\end{array}$ & 2515 & $\begin{array}{l}\text { They are unable to find higher cost of equity linking } \\
\text { with internal control weakness under Section } 404 \text {. } \\
\text { They infer that the disclosures of internal control } \\
\text { weakness have no potentially noticeable } \\
\text { cost-of-equity benefits. }\end{array}$ \\
\hline $\begin{array}{l}\text { Firm risk, } \\
\text { cost of } \\
\text { equity and } \\
\text { internal } \\
\text { control } \\
\text { deficiencies }\end{array}$ & $\begin{array}{l}\text { Ashbaugh } \\
\text { et al. } \\
\text { (JAR } \\
\text { 2009) }\end{array}$ & $\begin{array}{l}\text { SOX } \\
302 \\
\text { and } \\
404\end{array}$ & $\begin{array}{l}\text { November } \\
2003 \text { to } \\
\text { September } \\
2005\end{array}$ & 1053 & $\begin{array}{l}\text { Internal control deficiencies impact cost of equity and } \\
\text { firm risk under SOX } 302 \text { and } 404 \text {. They assert that } \\
\text { internal control weakness leads to low-quality } \\
\text { financial reporting, which in turn increases the } \\
\text { information risk that manifesting in high cost of } \\
\text { capital. }\end{array}$ \\
\hline
\end{tabular}


Table 7. Debt market and weakness disclosures

\begin{tabular}{|c|c|c|c|c|c|}
\hline Issue & Studies & Setting & Period & Sample Size & Results \\
\hline $\begin{array}{l}\text { The effect } \\
\text { of auditors' } \\
\text { internal } \\
\text { control } \\
\text { opinions on } \\
\text { loan } \\
\text { decisions }\end{array}$ & $\begin{array}{l}\text { Schneider } \\
\text { and } \\
\text { Church } \\
\text { (JAPP } \\
2008 \text { ) }\end{array}$ & $\begin{array}{l}\text { SOX } \\
404\end{array}$ & & 111 & $\begin{array}{l}\text { The lenders' assessment of the risk of extending a } \\
\text { line of credit and the probability of extending the line } \\
\text { of credit are negatively influenced when the company } \\
\text { receives an adverse internal control opinion as } \\
\text { compared to an unqualified one. They do not find any } \\
\text { evidence that the impact is lessened by the use of a } \\
\text { Big Four auditor. Additional analyses suggest that an } \\
\text { adverse internal control opinion weakens the } \\
\text { importance assigned to the balance sheet an income } \\
\text { statement in lending decisions and reduces lenders' } \\
\text { confidence that financial statements are presented } \\
\text { fairly in conformance with generally accepted } \\
\text { accounting principles. }\end{array}$ \\
\hline
\end{tabular}

\begin{tabular}{lllll} 
Internal & \multicolumn{2}{l}{ Costello } & SOX & September 2828 \\
control & et & al. & 302 & 2002 to \\
weakness & (JAR & & July 2008 \\
disclosures & 2011) & & \\
and debt & & & \\
contracting & & & &
\end{tabular}
contracting and Kim et al. SOX (AR 2010) 404

weaknesses

$\begin{array}{lll}\begin{array}{l}\text { Weakness } \\ \text { disclosures, } \\ \text { monitoring } \\ \text { and the }\end{array} & \begin{array}{l}\text { Dhaliwal } \\ \text { et al. (AR }\end{array} & \text { SOX } \\ \text { cost of debt } & & \\ \begin{array}{l}\text { Investor } \\ \text { perceptions }\end{array} & \begin{array}{l}\text { Lopez et (JAPP } \\ \text { af adverse }\end{array} & \text { 2009) } \\ \begin{array}{l}\text { internal } \\ \text { opinion }\end{array} & & \end{array}$

November 3640

3, 2004 and March 3, 2006

2005-2009 1363

3,2006
Internal control reports allow for the effectiveness of debt contracting. Accordingly, lenders decrease the use of financial covenants and substitute financial-ratio-based performance pricing provisions with alternatives when they face with weakness report. Also, lenders impose tight monitoring on manager (additional general covenants and decrease loan maturity), but do not decrease the use of financial covenants and financial-ratio-based performance pricing provisions.

High direct and indirect costs of bank loans are associated with control weaknesses. Further, banks charge higher loan rates after weaknesses disclosure and charge lower loan rates after weaknesses remediation. Entity-level control problems associated with higher loan rates compared to account-specific issues. Take as a whole, the results show that when banks set the price and non-price terms of loan contracts, internal control deficiencies are taken into consideration.

The results also show that the disclosure of material weaknesses results in high cost of debt. Additionally, the results are more significant when firms are not monitored by credit rating agencies and banks. This suggests that bank is an effective monitoring.

The authors find that adverse audit opinion associated with unqualified opinion related significantly to lower financial statement transparency, lower sustainability of earnings, lower earning predictability, higher risk of current and future financial reporting, higher information asymmetry, higher risk premium, higher cost of capital, and higher capital cost of the investor assessment. This suggests that adverse audit opinion covey incremental value relevant information to financial statement users. 
Table 8. Weakness remediation

\begin{tabular}{|c|c|c|c|c|c|}
\hline Issue & Studies & Setting & Period & Sample Size & Results \\
\hline $\begin{array}{l}\text { Qualification } \\
\text { improvement, } \\
\text { turnover of } \\
\text { CFO and } \\
\text { weaknesses } \\
\text { correction. }\end{array}$ & $\begin{array}{l}\text { Li et al. } \\
\text { (JAE } \\
2010)\end{array}$ & $\begin{array}{l}\text { SOX } \\
404\end{array}$ & 2004 & 2478 & $\begin{array}{l}\text { Remediation firms tend to experience more } \\
\text { turnover of CFO and hire CFOs having better } \\
\text { qualifications. Hiring a subsequent new qualified } \\
\text { CFO exhibits an improvement in fixing material } \\
\text { weaknesses. }\end{array}$ \\
\hline $\begin{array}{l}\text { Changes in } \\
\text { corporate } \\
\text { governance } \\
\text { and } \\
\text { subsequent } \\
\text { weakness } \\
\text { remediation }\end{array}$ & $\begin{array}{l}\text { Johnstone } \\
\text { et al. } \\
\text { (CAR } \\
2011)\end{array}$ & $\begin{array}{l}\text { SOX } \\
404\end{array}$ & $\begin{array}{l}2004- \\
2007\end{array}$ & 3602 & $\begin{array}{l}\text { Turnover of audit committee members rather than } \\
\text { board members, CEOs and CFOs relates positively } \\
\text { with remediation. If there are more independent } \\
\text { directors and financial expertises on boards, audit } \\
\text { committee members have more shareholdings, an } \\
\text { audit committee member acts as chairman, then } \\
\text { remediation would be improved. Additionally, the } \\
\text { greater accounting expertise, work experience and } \\
\text { good reputation of CFO benefit to weakness } \\
\text { remediation. }\end{array}$ \\
\hline $\begin{array}{l}\text { The impact } \\
\text { of } \\
\text { deficiencies } \\
\text { remediation } \\
\text { on accrual } \\
\text { quality }\end{array}$ & $\begin{array}{l}\text { Ashbaugh } \\
\text { et al. (AR } \\
\text { 2008) }\end{array}$ & $\begin{array}{l}\text { SOX } \\
404\end{array}$ & 2003-2005 & 1281 & $\begin{array}{l}\text { The firms whose auditor confirmed remediation of } \\
\text { previous reported maternal weaknesses exhibit } \\
\text { noticeable improvement in accrual quality compare } \\
\text { to the firms that failed to remediate weaknesses. }\end{array}$ \\
\hline $\begin{array}{l}\text { Remediation } \\
\text { of material } \\
\text { weakness and } \\
\text { changes in } \\
\text { earnings } \\
\text { quality. }\end{array}$ & $\begin{array}{l}\text { Bedard et } \\
\text { al. } \quad \text { (A } \\
2012)\end{array}$ & $\begin{array}{l}\text { SOX } \\
404\end{array}$ & 2004-2006 & 567 & $\begin{array}{l}\text { Company-level weaknesses are linked with lower } \\
\text { likelihood of remediation. Two remediation types } \\
\text { both improve significantly earnings quality. } \\
\text { Specially, some company-specific (accounting } \\
\text { reconciliation, information technology and } \\
\text { segregation of duties) and some account-level } \\
\text { (revenue, tax, inventory and receivables) } \\
\text { remediation types are slow but significantly tied to } \\
\text { change in abnormal accruals. }\end{array}$ \\
\hline $\begin{array}{l}\text { Internal } \\
\text { control and } \\
\text { conservatism }\end{array}$ & $\begin{array}{l}\text { Goh and } \\
\mathrm{Li} \text { (AR } \\
2011)\end{array}$ & $\begin{array}{l}\text { SOX } \\
302 \\
\text { and } \\
404\end{array}$ & $\begin{array}{lr}\text { Jan } & 2003 \\
\text { to } & \text { Nov } \\
2005 & \end{array}$ & 516 & $\begin{array}{l}\text { They observe that material remediation causes } \\
\text { greater conservatism compared to firms without } \\
\text { remediation by examining under SOX } 302 \text { and } 404 \text {. }\end{array}$ \\
\hline $\begin{array}{l}\text { Internal } \\
\text { control and } \\
\text { audit lag }\end{array}$ & $\begin{array}{l}\text { Munsif et } \\
\text { al. (A } \\
2012)\end{array}$ & $\begin{array}{l}\text { SOX } \\
404\end{array}$ & $\begin{array}{l}2008 \text { to } \\
2009\end{array}$ & 2839 & $\begin{array}{l}\text { They observe that audit lag is short for the firms } \\
\text { with remediation disclosure. While those firms } \\
\text { have higher lags compare to the firms without } \\
\text { remediation under SOX } 404 \text { in both } 2008 \text { and } 2009 \text {. } \\
\text { This suggests that material weaknesses cause the } \\
\text { reduction of audit lag. }\end{array}$ \\
\hline $\begin{array}{l}\text { Internal } \\
\text { control and } \\
\text { insider } \\
\text { trading }\end{array}$ & $\begin{array}{l}\text { Skaife et } \\
\text { al. (JAE } \\
\text { 2012) }\end{array}$ & $\begin{array}{l}\text { SOX } \\
404\end{array}$ & 2004-2008 & 4505 & $\begin{array}{l}\text { They observe that the firms disclose material } \\
\text { weakness benefit more from inside trading. Further, } \\
\text { they find that top managers are lack of integrity. } \\
\text { They also find that weak "tone at the top" CEOs } \\
\text { and CFOs tend to leave the firms when they engage } \\
\text { in insider trading with more profit. Overall, the } \\
\text { findings suggest that manager selling the shares of } \\
\text { firms is a greater risk of wealth transfer from } \\
\text { shareholders to managers. }\end{array}$ \\
\hline
\end{tabular}

